National Identities: critical inquiry into nationhood, politics and cultures (Taylor and Francis)

Special issue Architecture and Nation

Accepted for publication 05.07.2018

\title{
'A place for the unexpected, integrated into the city structure': universities as agents of cosmopolitan urbanism
}

Clare Melhuish

Keywords: universities, architecture, urbanism, cosmopolitanism, communities, ethnographic

\section{Abstract}

The role of formal architecture and urbanism in representing and reinforcing hegemonic power structures, ideologies, and identities is well-established (King 1990, 2004, Rabinow 1996, Yeoh 2001, Mishra and Hodge 1991). Universities, as élite institutions tied to state agendas (Bender 1988/1998/2002), and as major landowners, urban developers and financially well-endowed clients for architecture, have historically been significant actors in these processes. This paper discusses the evolution of new forms of university spatial and architectural development which are framed by discourses around inclusive, diverse, and cosmopolitan urban identities and heritage, transcending nationhood.

Introduction: from national identity to shared urban heritage

Drawing on recent case study research focused on the UK, US, and Sweden (Melhuish 2015), this paper visualises universities as agents of cosmopolitan urbanism, materialised through spatial and architectural interventions, in counterpoint to historic narratives of national identity in which they have been embedded. Bender describes how 'the modern academic disciplines were born in alliance with the rising nation state not the city... for its first century the modern university and nation have been more closely tied than the university and the city' (Bender 1998: 24). However university institutional development in the postcolonial context has moved away from an identification with nation and nationalist agendas, embracing globalised identity on the one hand, coupled with urban and metropolitan identity on the other: 'A place for the unexpected, integrated into the city structure', as the University of Gothenburg describes its new Project Näckrosen campus development: where 'people from different places and with different backgrounds will meet and work together..' ${ }^{1}$. In another example, the UCL 2034 vision embodies this shift with its re-branding of UCL as 'London's Global University', jumping from the urban to the global with no reference to the nation in between. New York's major universities, such as Columbia and New York University, also promote a strong focus on the role of the university in the city's economic strategy: the 'NYU in NYC' (NYU Framework 2031) brand sets out to position the institution as a globally networked university shaping the evolution of the city as an 'ideas capital' and hub of the knowledge economy. Urban universities in the younger postcolonial nation states of the global south are also increasingly focusing on internationalisation, 'world-class' status, and contribution to global development on the one hand, while promoting place-based community outreach and engagement with a variety of urban stakeholders on the other, including direct participation in urban development initiatives (see for example University of Witwatersrand in Braamfontein, Johannesburg²).

\footnotetext{
1 University of Gothenburg Project Vision, Project Campus Nackrosen $5^{\text {th }}$ March 2013

${ }^{2}$ Braamfontein Regeneration Project Business Plan: Version 2 July 2004
} 
Bender points out that one of the most distinctive features of major university institutions, drawing staff and students from across regions and around the world, is the way they ground complex, transnational, cosmopolitan communities and identities in local place - much like 'contemporary immigrant neighborhoods where residents live in local urban neighborhoods and diasporic networks' (Bender 2002: 162). He suggests that the sociology of the university is much like that of the city (Bender 1998). Across UK universities (and university cities) in 2015-16, 81\% of undergraduate students were from the UK, with $6 \%$ from the EU and $14 \%$ from the rest of the world, but $46 \%$ of students studying at postgraduate level were from outside the UK, with a large majority of international students coming from China at both levels ${ }^{3} .29 \%$ of staff in UK universities were from overseas in the same year, with $16.9 \%$ from the $\mathrm{EU}$ and $12.1 \%$ from outside the $\mathrm{EU}^{4}$. As Bender says, 'Teachers and students in a university, much like the new metropolitans, live at once in the past and the present, in a local place and a trans-local culture of international scholarship. They must constantly bring together in fruitful ways the past and present, the local and the trans-local' (Bender 2002: 162-163). This perspective provides a starting-point from which to investigate the impact of the university intervention, materialised in built form and space, on the wider spatial and social landscape of big cosmopolitan cities, made up of many diverse, mobile, cultural and ethnic communities.

The paper proposes that the two scales of urban and global identity can be brought together within a 'cosmopolitanist' vision of the university in its urban setting as a locus of intercultural contact and transnational flows, embodied by the university community. This vision then further shapes its relations and engagement at neighbourhood level with surrounding urban communities which are in many cases defined both by ethnic diversity and cultural difference, and by exclusion both from universities themselves and from the opportunities offered by the new evolving knowledge economies for which universities are the drivers. It will argue that, in counterpoint to critics of university-led redevelopment such as Bose (2015), many universities are engaging with an inclusive politics of development, framed by a concept of shared urban, as opposed to national, heritage, that can shape a discursive and material space to bring together 'centre' and 'periphery' in unequal postcolonial cities. As actors in urban development, universities have a primary responsibility for building place-based knowledge capital at metropolitan centres. But also, as significant urban landowners and developers, and, in many cases, centres of critical urban thought, they have the capacity to widen access to urban space and resources as well as education, and to promote a 'right to the city' (Lefebvre 1968) anchored in concepts of adaptive, democratic and cosmopolitan urbanism which transcend national identity and heritage.

Universities under pressure in the neoliberal city

In addition to their primary function of delivering higher education, universities around the world are becoming catalysts for city-based economic growth, particularly in relation to the knowledge economy: 'The urban location and centrality of universities to the nature and well-being of cities means that cities and countries can be expected to turn to their universities as part of strategies to respond to the new challenges and opportunities that global economic competitition

\footnotetext{
${ }^{3}$ https://www.ukcisa.org.uk/Research--Policy/Statistics/International-student-statistics-UK-highereducation

${ }^{4}$ http://www.universitiesuk.ac.uk/policy-and-

analysis/reports/Documents/International/International_Facts_and_Figures_2017.pdf
} 
poses for urban regions' (Wiewel and Perry 2008: 304; see also Perry and Wiewel 2005).

Universities are increasingly receptive to these expectations, partly because they are also subject to the pressures of an aggressive neoliberal higher education regime, linked to public funding cuts and a globalised marketised economy driven by metropolitan hubs of investment, development and profit (Addie Keil Olds 2015). Indeed, Harvey points out that universities have also had a responsibility for promoting neo-liberal models globally: 'the business schools that arose in prestigious univerities such as Stanford and Harvard, generously funded by corporations and foundations, became centres of neoliberal orthodoxy from the very moment they opened. ...by 1990 or so most economics departments in the major research universities as well as the business schools were dominated by neoliberal modes of thought. ...The US research universities were and are training grounds for many foreigners who take what they learn back to their countries of origin as well as into international institutions such as the IMF, the World Bank, and the UN' (Harvey 2005: 54).

Today, universities are increasingly expected by governments, city authorities, and other urban actors, to perform as drivers of this competitive, globalised, city-based knowledge economy, from which national public funding streams are steadily being withdrawn. Not only must they compete amongst each other for the best staff, students, and revenue streams, but they must also demonstrate impact in urban regeneration within a global network of cities, particularly through science and technology innovation and translation, medical research and partnerships, and job creation. These processes have been well-documented by economic geographers. Cochrane has described how many universities have assumed a proactive role as landowners and developers, generators of employment, and investors in roads and local government in the course of promoting their own spatial development projects (in the UK for example the University of Hertfordshire owns bus companies in Welwyn and Hatfield, while Falmouth University has launched a Shared Services Initiative whereby the University provides administrative and IT services to the local council). Their property strategies involve working with other developers, government and non-government agencies (such as local authorities and, formerly, Regional Development Agencies and Urban Development Corporations), public, private and third sector bodies, participating in wider urban processes (Cochrane 2013/15). Citing Allen and Cochrane, McCann Ward and Roy further underline the international and translocal context of these practices 'of actors who assemble policies from close by and elsewhere (Allen and Cochrane, 2007)... engaging with various policy networks and communities, stretched across the globe, in order to learn, teach, and share knowledge about best practice models' (McCann Ward Roy 2013: 583).

Driven then by competition (for reputation, staff and students) in an international marketplace, and, in the UK, released from financial constraints by the lifting of the cap on student fees (as recommended by the Browne Review 2010), universities engage in intense scrutiny of what their peers are doing, in order to produce locally embedded variants of global higher education models. These assume physical and spatial form within the parameters of distinct, but increasingly similar, city planning and urban regeneration contexts. Cochrane points to the surprising alignment of regional/local priorities and university priorities, despite different drivers' (Cochrane 2015), and to the circulation of a shared language and imagery in the promotion of these common interests. Alan Harding has also emphasised the role of universities as anchor institutions in the transition from an industrial to a knowledge economy, increasingly operating in collaboration with local authorities within a framework of 'growth coalitions and urban regimes' such as Local Enterprise Partnerships. As he says, they are in this sense beginning to catch up with American institutions 
which have been players in development strategies for a long time, positioned as businesses, deliverers of services, and attractors for new investment (Harding et al 2007, Harding 2013) - as well as drivers of urban renewal. Goddard and Vallance have explored the implications of this shift, pinpointing the question: 'Is the university in the city or part of the city?... we make the case for the civic university working with others in the leadership of the city in order to ensure that its universities are both globally competitive and locally engaged' (Goddard and Vallance 2011:1). Indeed, they argue that 'all publicly-funded universities in the UK have a civic duty to engage with wider society on the local, national and global scales, and to do so in a manner which links the social to the economic spheres' (Goddard 2009:4), building on established concepts of public service or civic mission, particularly as developed in US universities from the late $19^{\text {th }}$ century (Bromley 2006).

Responding to this context then, many universities are engaging in facilities expansion, spatial development, commercial research translation initiatives, community outreach and widening participation programmes. Addie explains that, 'As universities pursue diverse modes of organizational restructuring and roll out highly variegated spatial and institutional strategies they have a tremendous capacity to catalyze local economic growth and inform broader debates on responsive, adaptive, and sustainable urbanism through their research, teaching and outreach. For their part, policy makers (from the local to supranational) have embraced calls for universities to take on greater responsibility for their urban environments' (Addie 2018). Thus we see universities increasingly becoming implicated in hybrid, public-private models of urban development as 'anchor institutions' (Maurasse 2007, Work Foundation 2010) 'place-makers', and 'planning animateurs' (Benneworth and Hospers 2007), both through their own initiatives (for example UCL in the Olympic Park in East London) and at the invitation of commercial developers (as in the case of University of the Arts in London at Kings Cross and Elephant and Castle). But as HE institutions increase their capital investment in urban campuses and partnerships, and correspondingly expand their influence on the shape of urban landscapes, there is a surprising lack of documentation or analysis of university spatial development projects (van Heur 2010), or their effects on neighbouring communities. University-led urban transformations are embedded in larger processes of global, capital-led urbanisation exemplified by the landscapes of consumption, production, leisure, and capital accumulation in city centres (Smith 2002, Sywngedouw 2002). More often than not, these large-scale urban developments result in the displacement of weaker and more vulnerable urban communities, especially ethnic minorities, and the establishment of elite, often securitised enclaves (Bridge 2006, Caldeira 2000).

However, as centres of critical thinking, teaching and research, universities are not conventional developers and clients, nor are they perceived as such in the public domain. Increasingly, we see HE institutions promoting a rhetoric of urban regeneration, community participation, and inclusion (Bromley 2006), which counters the neo-liberal orthodoxies of the market-driven city, and shifts the focus from an urban/ civic to neighbourhood scale of engagement. Access to a broad range of funding sources and strong credit profiles further empower universities to promote such agendas, and to model alternative ideas about a more progressive and responsive urbanism and architectural practice in the postcolonial, cosmopolitan context. A significant number of institutions internationally are critically re-evaluating their relationship with the cities and neighbourhoods in which they are located, drawing on a development rhetoric of permeability, inclusivity, and opportunity, which acknowledges conditions of heightened mobility and intercultural contact, but also rising levels of inequality, in contemporary urban life, and the need for universities to address these problems (Melhuish 2015, Choueri and Myntti 2012, Rodin 2007, 
Maurasse 2001). The next section will examine the notion of universities as agents of a cosmopolitan urbanism that engages with these issues, transcending national boundaries, and interreferencing a global network of cities.

Universities in the postcolonial city

The socially and racially segregated colonial city (King 1990, Wright 1991, Rabinow 1989) was materialised in imposed, formal architecture at the centre, contrasting and intersecting with vernacular and informal building practices, often perceived as 'chaotic' (Edensor and Jayne 2011), at its margins. But what has been documented as a phenomenon of former colonial territories is now reproduced in postcolonial cities all over the world, in both the global north and south, where centre and periphery co-exist but rarely interact in localised urban spaces (Kearney 1995, Low 2006, n.d), and urban practice frames and stabilises increasing urban inequality, segregation, and exclusion, driven by globalised production and migration (Dikeç 2001). While universities, especially older institutions, are characteristically located in the civic and symbolic historic centres of cities, many are expanding their estates to the former industrial fringes of those areas and beyond, as anchors for regeneration as in London's 'special opportunity' areas, or New York's West Harlem district, site of Columbia University's new Manhattanville campus.

Nalbantoglu and Wong (1997) have framed a space for understanding postcolonial practice as one which intervenes in and disrupts models of architecture and urbanism 'that parade under a universalist guise and either exclude or repress different spatialities of often disadvantaged ethnicities, communities or people' - such as the classically-inspired civic monuments, including historic government and university buildings, of European, American, and colonial cities. Vernacular and informal types of architectural production at the margins are foregrounded as having an important role in the disruptive process, modelling alternative ideas about urban space, inclusivity and diverse identities. By example (and drawing to the centre urban theory 'from the periphery'), Letchimy analysed the self-built shanty towns (bidonvilles) encircling the colonial French-built city centre of Fort-de-France, Martinique, as as 'laboratories of the urban mangrove' working in symbiotic relation with the formal city. He proposed that this symbiosis could form the basis of a 'progressive and responsive caribbean contemporary urbanism, embedded in a new culture of democracy and ingenious approach to development', which would also offer a universallyapplicable model of shared, postcolonial urbanity (Letchimy 2011; Melhuish 2017).

Lefebvre critiqued the (French) university as a monumental and oppressive institution, colonising space around it (Lefebvre 1968, 19695); but he also explored its emancipatory potential as site of social struggle. As part of Ambasz's Universitas project of 1966, convened to examine how universities could become more responsive to the urban environment and affairs, Lefebvre identified the problem with the production of space under capitalism as being the necessity for 'comparability', as a basis for its commercial valuation and exchange across a global scale, resulting in a 'homogenization of fragments of commercialised space' (Ambasz 1966: 466-7) - across the world. Universities are entrenched in this game of commercial comparison and evaluation more than ever before - both institutional and spatial. But many are also recognizing the necessity of representing and building distinctive, grounded visions of themselves in relation to their urban neighbours, embedded in local situations, embodied in spatial development,and mediated by architects and communities (Melhuish 2015). 
The idea that universities can challenge the unequal distribution of cultural, social and financial capital which defines the divided city, both through their own institutional re-structuring to accommodate widening participation (particularly of students from local working-class and/or BAME backgrounds, and mature students with families), and through the modelling of inclusive urban and public space, constitutes a shift away from past ideas of the university as a project of elite universal knowledge production, represented by utopian and exclusionary spatial projects such as the University of Virginia. Jefferson's Academical Village, dominated by the Rotunda symbolizing knowledge and hierarchy, was described as 'incomparably the most amibitious and monumental architectural project... conceived in this century' by the New York Times in 1895. Instead, we find universities edging towards models of development which (referencing Nalbantoglu and Wong) 'disrupt' and 'intervene' in traditional universalising archetypes, and generate new ideas about hybrid forms of development. Alternative typologies are being evoked to describe a concept of embedded identity in the urban context which depends on building relationships among different communities, and blurs the boundaries between formal and informal development. In the UK, for example, the terms 'non-campus campus' (Durham Queen's Campus), 'living laboratory' (Newcastle University at Science Central), 'urban extension' (Cambridge University), 'communiversity' (Sheffield University), and 'collaboratory' (Bristol University) have entered circulation via university vision statements, development plans, and outreach initiatives, to indicate an evolution of institutional identity and modus operandi away from the so-called 'ivory tower' model of the past (Melhuish 2015).

This suggests a shift towards a more embedded, processual, and fluid conceptualisation of institutional and architectural identity, which hints at the 'concept of the possible' located by Holston (1996) in 'spaces of insurgent citizenship', defined by informal practices of architecture, urbanism and 'bricolage' (as for example in the bidonvilles of Fort-de-France, cited above). Holston clarifies the distinction between these kinds of spaces and 'the fundamentally different idea of alternative futures inherent in modernist planning and architectural doctrine'. While the first are fluid, adaptable and formative of an open and participatory concept of citizenship based on 'right to the city', rather than national identity, the latter are fixed, closed and implemented by the nation state, through its armies of technicians and engineers (as by contrast France's Opération Million in 1945). As Holston explains, 'Both express the basic paradigm of modernity which emphasises that alternative futures are indeed possible. But the insurgent and the modernist are competing expressions, which I will distinguish as ethnographic and utopian, respectively' (Holston 1996: pg 54).

I suggest that we can identify an ethnographic, rather than utopian, approach to space and its occupation driving an emerging cosmopolitanist - as opposed to monolithic - vision of university identity defined in relation to urban neighbours, and its materialisation through built and lived space in the postcolonial context. While the first is people-centered, observant of existing practices of everyday life in urban settings, responsive to detail, and open-ended, the second is imposed as an ideal, universal, technical and finished schema, regardless of physical or social context. Embracing the reality of the postcolonial city as a 'laboratory of the urban mangrove' involves challenging the technocratic control of urban space, and creating space for 'ingenious development' (Letchimy 2011) which resists the temptation to cast universities as the crucible for cultural formation. It recognizes that spatial dynamics stabilise social problems leading to their reproduction (Dikeç 2001), while re-framing notions of citizenship as a 'cosmopolitan project' (Binnie et al 2006) - 'the world as both a single place and one comprised of multiple differences' (ibid: 5) - through inclusive 
spatial development capable of accommodating both formal and informal practices. The next section, then, will consider the tools and discourses which two universities are using to promote a vision of university and urban identity which might be framed as ethnographic and 'cosmopolitanist' in the context of the charged spatial politics of the postcolonial city.

Universities and the production of urban space and identities

As this paper has asserted, universities have assumed an increasingly important role in the control and production of urban space, linked to the development of hybrid (public/private) models of urban development and funding structures, and become deeply implicated in the contemporary politics of urban space and spatial justice, often to their detriment. Bose, for example, with reference to Ohio State University in the USA, draws critical attention to 'universities as important actants in the neoliberal city, specifically through their engagement of development activities... [which] typically means destruction of existing living and workplaces'. She attributes their behaviour as 'entrepreneurial subjects' (Foucault 2008) to the 'pressures coming out of the accumulation process' (Bose 2015: 2617). In a wider context, Jaffe (2013) has also highlighted the implications of the diversification of multiple governmental actors (among which we can include universities and other public institutions) sharing control of urban space, for the spatial politics of urban inequality, and understandings of citizenship under neoliberalism.

The distinctive feature of university development which seems to set it apart from typical accumulative forms of corporate or commercial property development is an underpinning narrative of identity and purpose which extends beyond the maths around student numbers and income from teaching and research, and varies from institution to institution - shaped by its own founding charter and heritage, and increasingly embedded in the wider discourse of local urban place-making in which universities are both positioning themselves and being positioned by external forces. The development and communication of this narrative in both verbal and visual form performs a vital function not simply in representing or projecting a future identity for the university, but also in building social relationships and alliances among the different actors implicated in it and negotiating dissent within the free-thinking academic community. Thus in order to mobilise support both internally and externally for their spatial and material expansion projects in the city, universities are drawing on historical narratives of institutional and urban heritage rather than national identity or discourses of nation-building. This reflects shifts in the conceptualisation of shared heritage at a grander scale. Stuart Hall indicates two key factors at work in the UK in changing received understandings of 'the National Heritage' as the material embodiment of 'a shared national identity ... deeply embedded in specific "ethnic" or cultural meanings... a collective social memory'. They are, firstly, 'the democratisation process', and secondly, 'the critique of the Enlightenment ideal of dispassionate universal knowledge... coupled with a rising cultural relativism which is part of the growing de-centring of the West and western-oriented or Eurocentric grand-narratives' (Hall 1999). Both of these have had a significant influence on the ways in which universities frame their institutional identities and missions, and their relationships with other communities in postcolonial, multi-ethnic cities with whom they seek to engage in the construction of a shared urban heritage.

Here I will focus on two contrasting case studies for critical analysis of the ways in which notions of participation and engagement, permeability, inclusivity, urban encounter, and opportunity, are being referenced by universities as part of a discourse of shared urban and cosmopolitan heritage, side-stepping national identity, in order to build support and alliances among local and citywide stakeholders for their development projects in the city, and to mediate 
the spatial politics of these interventions. I will suggest that these processes contribute to the creation of a discursive and material space in which to challenge the inequalities and spatial injustices of the postcolonial city, and position the university as agent of place-based cosmopolitan urbanism, drawing together diverse communities from home and abroad.

UCL East in London and University of Gothenburg's Project Näckrosen, both due to open in 2020, are two significant university development projects of different scales, which nevertheless exhibit a number of relevant comparable features. Both are sited at locations of historic significance in their respective cities' histories - the Olympic Park in Stratford, east London, home of the socalled 'London 2012' Olympic games (notwithstanding the national significance of the event) and currently undergoing redevelopment as part of the Olympic legacy scheme for the regeneration of the area; and the site of the Gothenburg Exposition of 1923, which was subsequently redeveloped as the Liseberg Amusement Park at Korsvagen, and the city's cultural centre - including the art museum, library, and concert hall at Götaplatsen and, later, several university buildings including the publicly-accessible university library behind it at Näckrosen. Both projects have aroused considerable controversy both within the university, and in the local neighbourhoods in which they will be built. They have also implicated the universities in new kinds of engagements with the relevant urban planning authorities, design consultants, community organisations, and their own student and faculty bodies which have brought city-centered discourses of heritage, identity and belonging to the fore.

University visions of development comprise two dimensions: the institutional, embracing the structure and organisation of the university as an educational institution; and the physical - the university as a particular kind of place where research and teaching are carried out. But often there is a dysjunction between the two. Academics and administrators may not consciously visualise universities as physical places, but rather as a complex organisation of teaching and research programmes that need to be accommodated. Estates teams may only see universities as spatial and operational entities which pose particular issues around maintenance and running costs.

Communication between the two is often fraught with tensions, and further complicates the process of communication between the university as a unified entity with the heterogeneous communities outside it which have an interest in its plans. Thus when spatial development projects come onto the horizon, masterplanners, architects, and engagement consultants are often brought in to develop a three-way mediation process. Then, that vision needs to be communicated to wider audiences beyond the university, to build support for the project, both through statutory consultation exercises, and other types of research and outreach initiatives shaped by that ambition. At this stage, concepts of shared, place-based heritage and participation are often evoked to mediate the spatial politics in which universities are entangled as powerful and influential institutions.

Both UCL and University of Gothenburg have framed their vision for new development around the need for innovation, openness, integration with city neighbours, and a regeneration of urban culture in two cities which are home to significant ethnic minority communities. London's multi-ethnic population is well-established since mass migration began in the postcolonial period, but tends to be concentrated in the city's poorer neighbourhoods and disproportionately affected by social and spatial inequalities. Gothenburg has been a host city for incoming migrants and refugees particularly from Eastern Europe, the Middle East and Africa since the 1990s, with a dramatic increase in recent years which has led to heightened political tensions around issues of integration, segregation and conflict in the city's suburbs. In both of these university case studies 
there is an underlying sub-text around widening access and the role or responsibility of the university in 'making space' for diverse communities of different ethnic and cultural heritage in a common urban context.

The underlying driver for expansion and redevelopment in UCL's case was a lack of space in central London (at its historic Bloomsbury site), and a desire to promote more effective crossdisciplinary collaboration supported by larger, more flexible facilities. The university's Estates team led on the project from the start, and selected the Olympic park site from a number of sites around London primarily because of its connectivity to transport infrastructure via the Stratford local and international hub, and because of the offer of a significant government subsidy to develop the site as part of the Olympic legacy regeneration scheme. For the University of Gothenburg, the primary rationale for the project to build a new Faculty of the Arts and Humanities and library, along with the conversion of the adjacent County Court building into university facilities, was the desire to consolidate university facilities at one site and foster better co-operation between departments, creating a new 'knowledge park for humanities and arts' linking Götaplatsen (culture district) and Korsvagen (events district) in the city centre.

$\mathrm{UCL}$ is working in partnership with the London Legacy Development Corporation to develop its new site, called UCL EAST to signpost not only its geographical location but also its areas of academic focus - Experiment, Arts, Society and Technology - and its 'commitment to creating a vibrant, diverse and accessible campus in, of and for East London... [which is] open and highly collaborative with external organisations' (UCL East Vision ${ }^{6}$ ). UGOT is working with Akademika Hus (a government property subsidiary which owns and manages university buildings nationally) and the City of Gothenburg to create a 'cornerstone of the University' which will also be part of a general development process creating 'a new attraction for Gothenburg as a city of culture and knowledge' (Vision 2020), celebrating its $400^{\text {th }}$ anniversary. Both universities have developed vision statements and strategies over the last five years which have involved complex negotiations and conversations with many different stakeholders within and outside the institutions, and generated a range of narrative and visual imageries to support their respective projects. But these processes have also generated controversy, opposition, and some uncomfortable self-interrogation as a result of the real urban encounters and spatial politics implicated in development on the ground, in two very different social contexts: in Gothenburg, an élite bourgeois neighbourhood around an exclusive city centre park; in London, a socially-deprived, multi-ethnic peripheral area of blighted opportunity, desperately in need of employment and affordable housing. In response, both universities have used heritage discourses to link their own institutional ambitions to wider urban and community interests at their particular sites - the Olympic Park, and the Gothenburg Exposition site.

The Gothenburg Exposition was a 'mega event' of its time produced to mark the city's $300^{\text {th }}$ anniversary and showcase its strengths as an industrial and mercantile centre. It was dominated by the vertical centrepiece of the Memorial Hall, which stood on an elevated site at the end of the extended axis formed by the Avenue (Avenyn) linking to the historical centre of the city. This building had no function other than to hold a book in which visitors to the expo signed their names, and was demolished after the event. It was on this site that the horizontal redbrick buildings of the university's Arts and Humanities Faculty and adjacent library were constructed in the 1960s. Under the current plans these buildings will be replaced with modern, vertically-oriented facilities, linked to a major new transport interchange at Korsvagen to the east, and a commercial redevelopment of

${ }^{6}$ http://www.ucl.ac.uk/ucl-east/at-a-glance/vision 
the whole Avenyn axis (private developer) running north to the historic city centre. The university proposals evoke a rediscovery of the expo area, symbolised by the new four-storey faculty building and its formal pillared façade. It has been described by a member of the project team as 'a sort of neurotic repetition of the Gothenburg Exhibition in 1923; the same rhetoric is employed in order that we are granted permission... That we will renew the city with the help of art and humanities and industry: it's exactly the same discourse' ${ }^{7}$.

The university's own heritage is encapsulated in its institutional motto: 'to innovate tradition and traditionalise innovation' (tradita innovare innovata tradere). It grew out of the need to meet the demands of the city's emerging professional life, in contrast to the traditional élite universities of Lund and Stockholm. Its leaders were prominent people in business, and it was informed by the ideals of a modern university engaged with society. Its physical infrastructure is widely distributed across the city centre, but institutionally it is characterised by a lack of cooperation between those departments scattered throughout the urban fabric, leading to the current concern for consolidation. The preliminary architectural visualisations for the Project Näckrosen site showed a 'closed-off campus area', made up of 'heavy buildings in a park landscape' (project team member). The suggested loss of existing green space created a lot of tension with the small population of wealthy, well-educated citizens who live around the area, some of whom had studied conservation. They constructed an argument around the heritage value of the County Court building in order to defend against the intrusion of the University on the park, framed as a heritage contested space in which the court building became the focus of a 'fight about the past'.

Meanwhile, left-leaning academics also opposed the project on the basis that the university should be planning to locate any expansion 'outside the city centre, in precarious areas... in a segregated Gothenburg suburb' - comparable to east London.

As Project Director, Johan Oberg worked to build a sense of collective interest around the project 'in the name of a better shared future for all interested parties' and as a 'negotiated University agenda'. This was achieved by getting rid of the early visualisations, and organising a series of seminars, in which the 'strong administrative real estate agenda could be articulated with internal academic critique', and then communicated to different groups of resistance in the area with a focus on the symbolic value of the Exposition site in the city's history, re-presented in the university's development plans. This involved a careful framing of the development itself as a 'pure academic project', keeping its distance from city planning politics and any perceived complicity with the transformation of the traditional working class city into 'a new globalised entity dominated by intellectual production', which would not fit with the idea of a common mercantile urban heritage. At the same time, it developed a focus around the planning of the new library to engage with heritage issues around books and digitisation, and the problems posed by 'migrants in need of an intellectual shelter in the big city', a key issue in relation to Gothenburg's status as the most segregated city in Sweden.

Like Näckrosen, the Olympic Park has emerged as a highly contested heritage space both since and pre-dating the London games in 2012, in which UCL's intervention has brought existing tensions with poor, multi-ethnic local communities in the surrounding boroughs to the fore. As a

\footnotetext{
7 all quotes taken from presentations made by project team members at Universities and urban heritage: two closed workshops organised by Curating the City research cluster in the UCL/UGOT Centre for Critical Heritage Studies, London Nov 2016, and Gothenburg April 2017; and from interviews with project team members conducted in April 2017
} 
significant site in London's industrial history, which supported around 600 businesses and 1,000 residents before they were evicted to make way for the games, it became a tabula rasa for the construction of new narratives of sporting excellence and national identity in the run-up to 2012. Now the park is infused with a heritage of sport represented by the numerous Olympic monuments that remain: 'architectural icons that are dotted around' (as described by UCL East's former project director) within the perimeter of the park, symbolising the disconnect that exists between what goes on inside and outside its boundaries. UCL East is part of a wider initiative to bring a number of high profile cultural and educational institutions into the park as an anchor for urban regeneration in East London, and to mitigate the overspend on the Olympic games by securing long-term benefits for the area in the form of jobs, training, and housing. In return for its government subsidy, UCL has positioned itself at the centre of a transformative urban heritage discourse which holds up the future of east London at the centre of the new, inclusive knowledge economy as a logical outcome of its former industrial past, and promises to deliver positive changes at local level in parallel with its remit for global engagement and recognition: 'UCL is very much upholding the LLDC's objectives in terms of delivering regeneration, being sustainable, being interactive, open, welcoming and not being an élite centre but something that welcomes the local people in' (UCL East former project director).

This positioning also taps into UCL's own institutional history and heritage: 'UCL was quite a leading progressive liberal [institution], it had an aspiration to open up to a range of students [as a non-religious foundation], though women still weren't allowed until the late $19^{\text {th }}$ Century'. UCL's non-conformist, 'effortlessly radical' and egalitarian origins are emphasised in its academic vision statement for the new campus as a guarantee of its intent to 'discover, co-create and share new knowledge for the benefit of all' ${ }^{8}$. It is echoed in its promise to deliver a physical development which will connect UCL East to its surroundings and 'invite people in', with a 'vibrant public space' at its heart. Whereas UCL's Bloomsbury campus architecture 'really comes from a root of privilege, authority', UCL East, 'both physically and ... culturally, ... has this challenge of creating these new, almost stand-alone $21^{\text {st }}$ century buildings and trying to make itself part of East London' ${ }^{9}$ In contrast to University of Gothenburg, UCL's approach to this problem has been to separate its community engagement activities from the academic sphere, investing them in a specialised 'public engagement unit', and impose a moratorium on architectural visualisations in the early stages of concept development and masterplanning in order to avoid miscommunication, while also creating a vacuum of information. In parallel, many of UCL's academics have also developed relationships with local groups through different kinds of community-based research activities. But little of either the public engagement or the academic work has fed in to the masterplanning and design development of new buildings on the site. From the project team perspective, 'the poor quality of [neighbouring] housing from the 1960s' suggested that 'there's very little long-term heritage there' from which to develop an appropriate design proposal. In response, the masterplanners developed a 'fluid concept' for the new campus, 'trying to develop a ground-plane which is open and accessible across the entire piece', while preserving a more cloistered academic privacy at the upper levels, but potentially creating a disconnect 'between the kinds of buildings that are happening in the park, the sorts of places we are creating there, and the historic fabric that we see to the south' (former project team member).

${ }^{8}$ http://www.ucl.ac.uk/ucl-east/at-a-glance/vision

${ }^{9}$ quotes from interviews with former UCL East project director April 2017 
Many in those surrounding local communities have objected to UCL's re-writing of the area's urban heritage, and the effects of gentrification which they anticipate will define its future identity. But ultimately the UCL East project makes little reference either to its historic (industrial) or more recent (Olympic) past and social identity, in favour of a focus on a projected shared future heritage, embodied in the buildings of the new campus and the activities they will host, as a new powerhouse for London. Both the UCL and Gothenburg developments disclose a highly city-based rhetoric around integration with the city fabric, and the creation of new kinds of university spaces which are permeable, inclusive, and afford new kinds of social interactions between the university community, its urban neighbours, and newcomers to university sites as a kind of 'shelter' in the city. At UCL these include outward-facing facilities intended for public engagement, such as a new Urban Room, a library and learning centre available for public use, and open spaces within the campus area which are accessible to the public. At Gothenburg, the library is again the focus of attention, and although the café in the faculty building which is currently open to the public will no longer exist, proposals to turn the old courthouse building into a creative hub for university interactions with the public are under discussion.

In both cases this rhetoric draws on existing narratives of university heritage and identity, projected into symbolic urban heritage contexts, which provides a framework for the construction of social relationships and alliances around the development, engaging with issues of diversity and exclusion - even through the processes of confrontation and opposition which it generates.

However when it comes to the objectification of such discourses as built form, there is always a risk of failure. The complexity of claims for access to space and representation in the city, especially cosmopolitan, postcolonial cities beset by inequalities, poses enormous challenges to the fixity and pace of conventional project management and delivery structures. As centres of critical thinking, research and teaching, universities therefore need to mobilise their resources to address and engage more explicitly with these issues, if they are to fulfil their role and responsibilities with regard to the construction of more fluid and 'ethnographic' urban heritage narratives, embracing a range of different voices. Somewhere between enclaved and exclusionary urban complexes of privatised, 'smooth' space designed to sustain elite circuits of cosmopolitan cultural capital on the one hand (Bridge 2006, Caldeira 2000), and left-over segregated spaces occupied by the (often racialised) marginal and dispossessed on the other (Elsheshtawy 2011, Kelly 1993), universities have the capacity to shape new, hybrid urban spaces to accommodate forms of diverse and transnational citizenship, that transcend nationalist discourses. As cosmopolitan communities of practice, property owners and institutional developers, they are well placed to facilitate that encounter with difference and inter-mixing capable of promoting a 'civic culture from the interactions of multiple publics' which Sandercock called for in the cosmopolis (Sandercock 1998, 186-7).

\section{References}

Addie, J-P., Keil, R., Olds, T., 2015, Beyond town and gown: universities, territoriality, and the mobilisation of new urban structures in Canada, Territory, Politics, Governance, 3,1: 27-50 Addie, J-P., 2018, Urban(izing) university strategic planning: an analysis of London and New York City, Urban Affairs Review, published online before print 2018, 3

Bender, T. ed, 1988, The university and the city: from medieval origins to the present. Oxford: OUP; Ambasz, E., 1966, The Universitas project: solutions for a post-technological society. NY: MOMA, 466-7 
Bender, T. 1998, Scholarship, local life, and the necessity of worldliness, in van der Wusten, H., ed: The urban university and its identity: roots, location, roles. Dordrecht, Boston, London: Kluwer Academic Publishers 1998, pp 17-28.

Bender, T. 2007 (2002), The unfinished city: New York and the metropolitan idea. NY: The New York Press

Benneworth, P., and Hospers, G-J., 2007, Urban competitiveness in the knowledge economy: universities as new planning animateurs, Progress in planning 67

Benneworth, P., Charles, D., and Madanipour, A., 2010, Building localised interactions between universities and cities through university spatial development, European Planning Studies 18: 10, 1611-1629

Binnie, J. Holloway, J., Millington, S., and Young, C., 2006, Cosmopolitan urbanism. Abingdon: Routledge

Bose, S, 2015, Universities and the redevelopment politics of the neoliberal city, Urban Studies 52 (14) 2616-2632

Bridge, G., 2006, 'The paradox of cosmopolitan urbanism: rationality, diffrence and the circuits of cultural capital', in Binnie, J., et al (eds) Cosmopolitan urbanism. Abingdon: Routledge, 53-69 Bromley, R., 2006, On and off campus: colleges and universities as local stakeholders, Planning, Practice, and Research 21: 1, 1-24

Caldeira, T., 2000, City of walls: crime, segregation, and citizenship in São Paulo. Berkeley: University of California Press

Choueiri, T., and Myntti, C., 2012, The AUB Neighborhood Initiative: Social Responsibility in a University's Backyard, in Jamali, D. and Sidani, Y., eds., CSR [Corporate Social Responsibility] in the Middle East: fresh perspectives. SpringerLink pp 158-175

Cochrane, A., speaking at Univercities 1: Space: universities, cities and globalisation, UCL Urban Laboratory, $9^{\text {th }}$ May 2013; and at The Urban University: universities as place-makers and agents of civic success in medium-sized towns and cities, University Town Northampton project, Northampton July $2^{\text {nd }}-3^{\text {rd }} 2015$

Cochrane, A and Williams, R., 2013, Putting higher education in its place: the socio-political geographies of English universities. Policy and politics, 41:1, 43-58

Dikeç, M., 2001, Justice and the spatial imagination, Environment and Planning A, volume 33, pages 1785-1805

Edensor, T., Jayne, M. (Eds.), 2011, Urban Theory Beyond the West: A World of Cities. Routledge, London

Elsheshtawy, Y., 2011, 'Urban (Im)mobility: public encounters in Dubai', in Edensor, T., and Jayne, M., (eds) Urban theory beyond the west: a world of cities. London: Routledge, pp 219-236

Goddard, John, 2009, Reinventing the civic university. Provocation 12, London: NESTA

https://www.nesta.org.uk/sites/default/files/reinventing the civic university.pdf

Goddard, John, and Paul Vallance, 2011, 'The civic university and the leadership of place'. CURDS

Newcastle University. http://www.talloires2011.org/wp-content/uploads/2011/06/Civic-Universityand-Leadership-of-Place-John-Goddard.pdf

Hall, S., 'Un-settling the heritage, re-imagining the post-nation. Whose heritage?' Third Text 13: 49, 3-13, 1999, pp4-5

Harding, A., speaking at Univercities 1 seminar, UCL, May 2013

Harding, A., Scott, A., Laske, S., and Burthscher, C, eds, 2007 Bright satanic mills: universities,

regional development and the knowledge economy. London: Routledge

Harvey, D., 2005, A brief history of neoliberalism. Oxford: OUP

Heur, B van, 2010 The built environment of higher education and reearch: architecture and the expectation of innovation. Geography Compass 4/12: 1713-1724

Holston, J., 1996, Spaces of insurgent citizenship, in Melhuish, C., ed, Architecture and anthropology, AD Profile 24. London: Academy Editions 
Iveson, K., 2006, Strangers in the cosmopolis, in Binnie, J. et al, Cosmopolitan urbanism. Abingdon: Routledge, pp 70 - 86

Jaffe, R., 2013, The hybrid state: crime and citizenship in urban Jamaica. American Ethnologist 40:4 734-748, 2013

Kearney, M., 1995 The Local and the Global: The Anthropology of Globalization and

Transnationalism, Annual Review of Anthropology, Vol. 24 (1995), pp. 547-565

Kelly, MFP, 1993, Rethinking citizenship in the global village: reflections on immigrants and the undercalss. New York: Russell Sage Foundation. Working Paper 38

King, A., 1990, Urbanism, colonialism and the world economy: cultural and spatial foundations of the world urban system. London: Routledge

King 2004, Spaces of global cultures: architecture, urbanism, identity. London: Routledge

Lefebvre 1968, Le droit a la ville. Paris: Editions Anthropos;

Lefebvre, H., 2003 (1970). The urban revolution. Minneapolis: University of Minnesota Press.

Letchimy, S., L'urbanisme, d'hier à demain, ou l'art de la transmission (extract), Lyann Karayib,

Cahier Ville Caraibe, No. 1, Fort-de-France: Centre de ressources Ville caraibe, 2011

http://www.villecaraibe.com/docs/Lyann\%20Karayib01BonDeCommande.pdf

Low, S., 2006, The anthropology of cities: imagining and theorizing the city. Annual Review of Anthropology 25: 383-409

Low, S., n.d., Public Space and Diversity: Distributive, Procedural and Interactional Justice for Parks Maurasse, David, Beyond the campus: how colleges and universities build partnerships with their communities. New York, London: Routledge, 2001

Maurasse, D., City Anchors: Leveraging Anchor Institutions for Urban Success, CEOs for Cities.

Chicago, IL, 2007

Melhuish, C., 2015, Case studies in university-led urban regeneration. London: UCL Urban

Laboratory

Melhuish, C., Degen, M., and Rose, G., 2016, 'The real modernity that is here': understanding the role of digital visualisations in the production of a new urban imaginary at Msheireb Downtown, Doha; City and Society 28:2

Melhuish, C., 2017, 'Aesthetics of social identity: re-framing and evaluating modernist architecture and planning as cultural heritage in Martinique', Planning Perspectives,

DOI: $10.1080 / 02665433.2017 .1389659$

McCann, E., Kevin Ward and Ananya Roy, 2013, Urban pulse - assembling/worlding cities. Urban Geography, Vol. 34, No. 5, 581-589

Minigione 1993

Mishra, V. and B. Hodge, 1991, What is post-colonialism? Textual Practice 5, 1991, 399-413

Nalbantoglu, G. B and Wong, C.T, 1997 Postcolonial Space(s). New York: Princeton Architectural

Press

New York Times 1895

Perry, David C., and Wiewel, W., eds., 2005, The university as urban developer: case studies and analysis. Armonk NY: M. E. Sharpe

Rabinow, P 1989, French modern: norms and forms of the social environment. Cambridge MA: MIT Press

Smith, N, 2002, 'New globalism, new urbanism: gentrification as global urban strategy', in Brenner, N., and Theodore, N., Spaces of neoliberalism: urban restructuring in North America and western Europe. Oxford: Blackwell, pp 80-103

Rodin, J., 2007, The University and Urban Revival: Out of the Ivory Tower and into the Streets, Philadelphia: University of Pennsylvania, 2007 182-3

Sandercock, L., 1997, Towards Cosmopolis: planning for multicultural cities. Chichester: Wiley Swyngedouw, E., Moulaert, F., and Rodriguez, A., 2002,'Neoliberal urbanization in Europe: largescale urban development projects and the new urban policy', in Brenner, N., and Theodore, N. 
Spaces of neoliberalism: urban restructuring in North America and western Europe. Oxford: Blackwell, pp 80-103

Watson, S, 2006, City publics: the (dis)enchantments of urban encounters. London: Routledge Werbner, P., 2008, Anthropology and the new cosmopolitanism: rooted, feminist and vernacular perspectives, Oxford: Berg

Wiewel, Wim and David C. Perry, eds., 2008, Global universities and urban development. Armonk NY: M.E.Sharpe

Wright, G, 1991, The politics of design in French colonial urbanism. Chicago; London: University of Chicago Press.

The Work Foundation, 2010, Anchoring growth: the role of anchor institutions in the regeneration of UK cities. Research paper 2 in Regeneration Momentum, The Northern Way

Yeoh, B.S.A. Postcolonial cities. Progress in Human Geography 25, 2001, 456-468.

Figures (indicative)

1. aerial view Olympic Park_UCL East site

2. UCL East Final draft masterplan 2016

3. UCL East Final draft masterplan SECTION

4. view of existing Faculty of Arts and Humanities at Nackrosen

5. visualisation of part of future development at Nackrosen

\section{NOTES ON CONTRIBUTOR:}

Clare Melhuish is Director and Senior Research Associate in the UCL Urban Laboratory, where she has been working on the role of university spatial development projects in urban regeneration and the production of cosmopolitan urbanism and imaginaries in the UK and abroad. She is Deputy Director of the Bartlett Global Centre for Learning Environments. Her background lies in architectural history and criticism, anthropology, and cultural geography. She draws on ethnographic and visual research methods to interpret and understand architecture and the built environment as social and cultural setting. Her particular areas of interest and expertise include Modern Movement and contemporary architecture, postcolonial urban aesthetics and heritage, and urban regeneration policy and practice, with specific area specializations in the architecture and planning of the UK, France, the Gulf and the Caribbean. She works both within and beyond the academic context, drawing on many years' experience as a journalist, author, and curator in architecture and design. 



$+3$

P.

(iv)

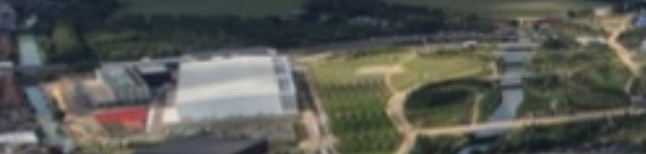

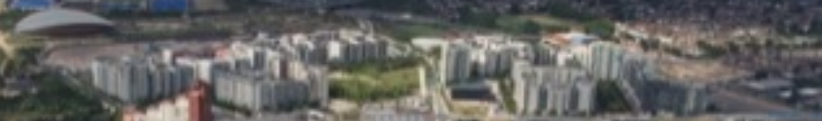



\section{$200=$



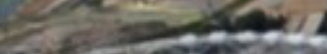
1日in-

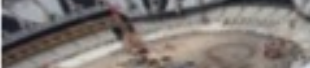

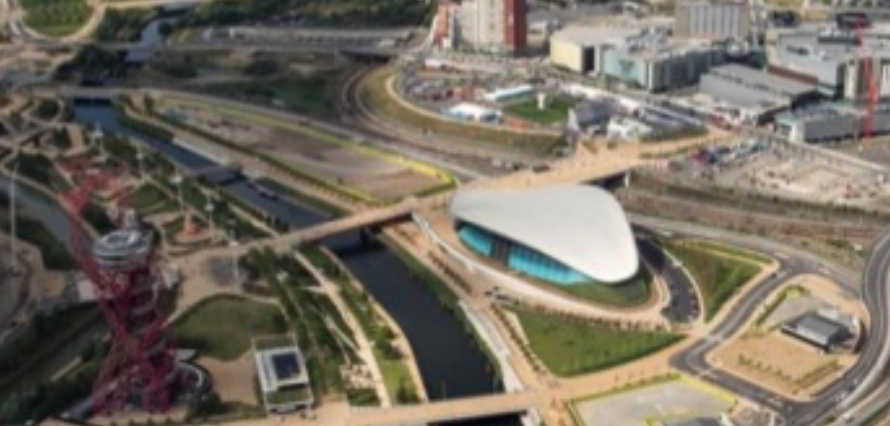



Q


1.2.


$=\infty)^{3}$
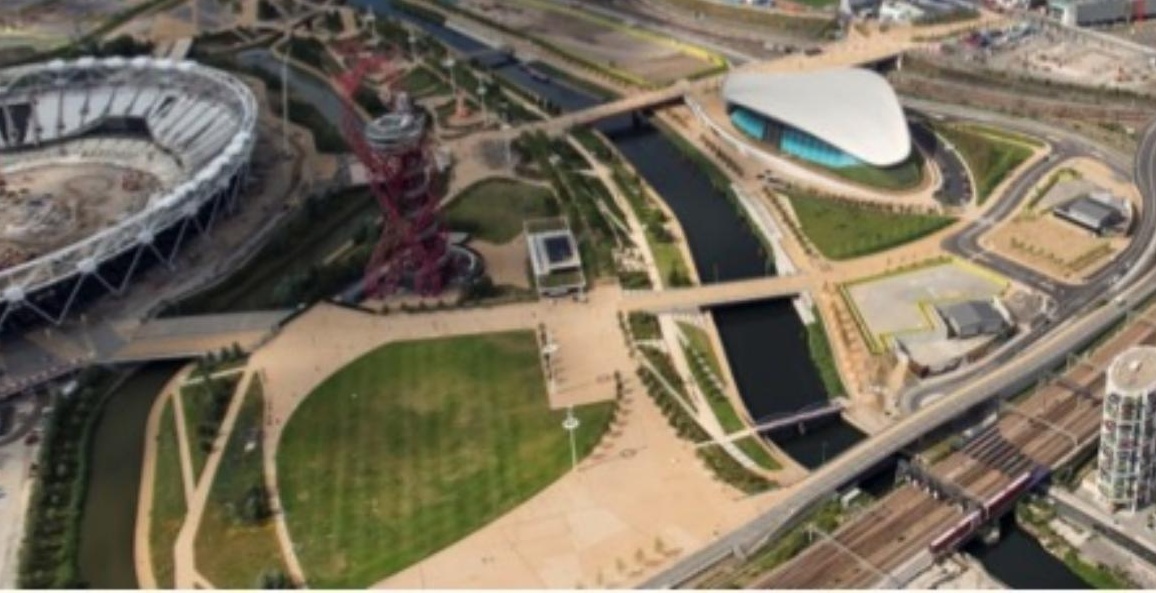

4.



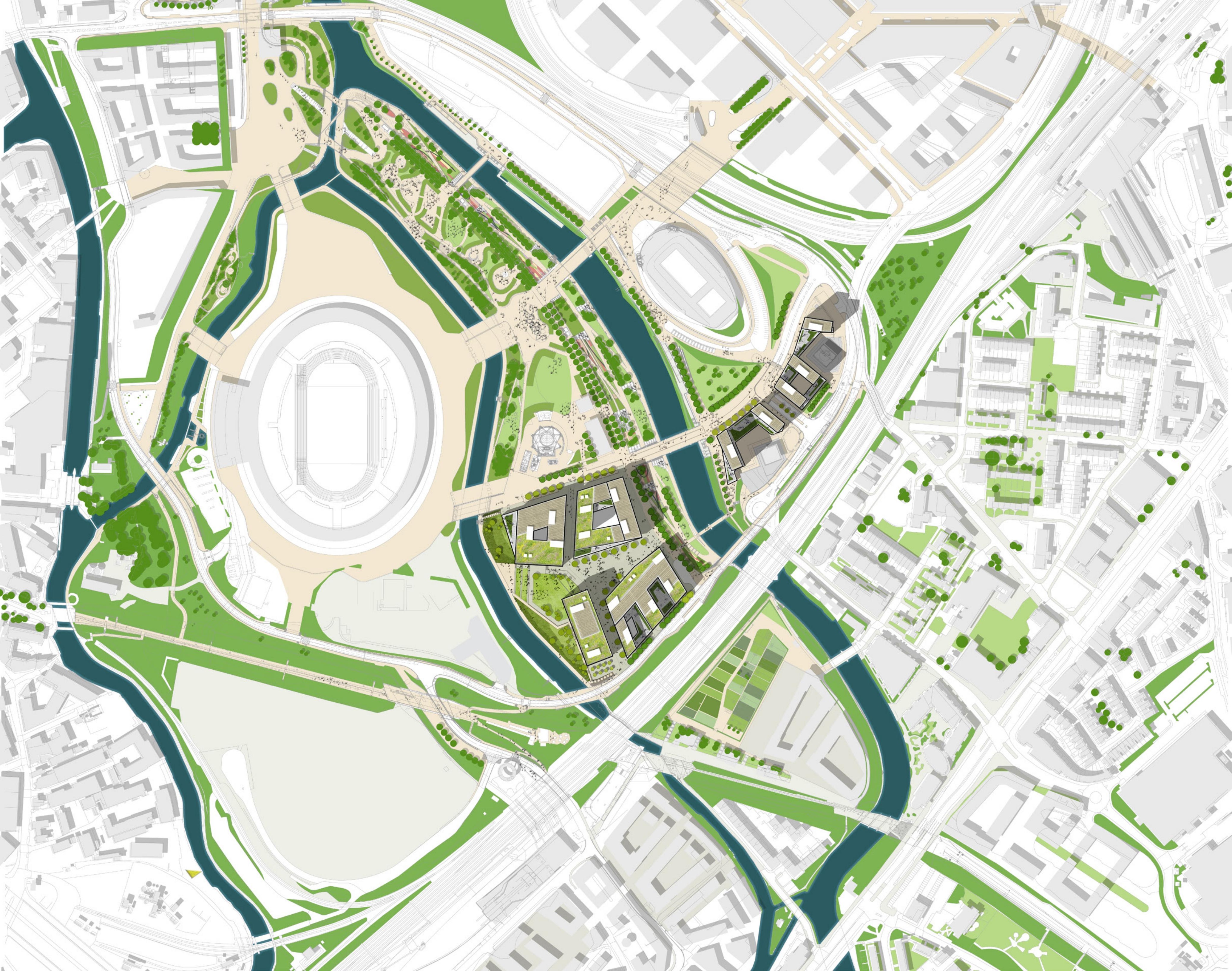



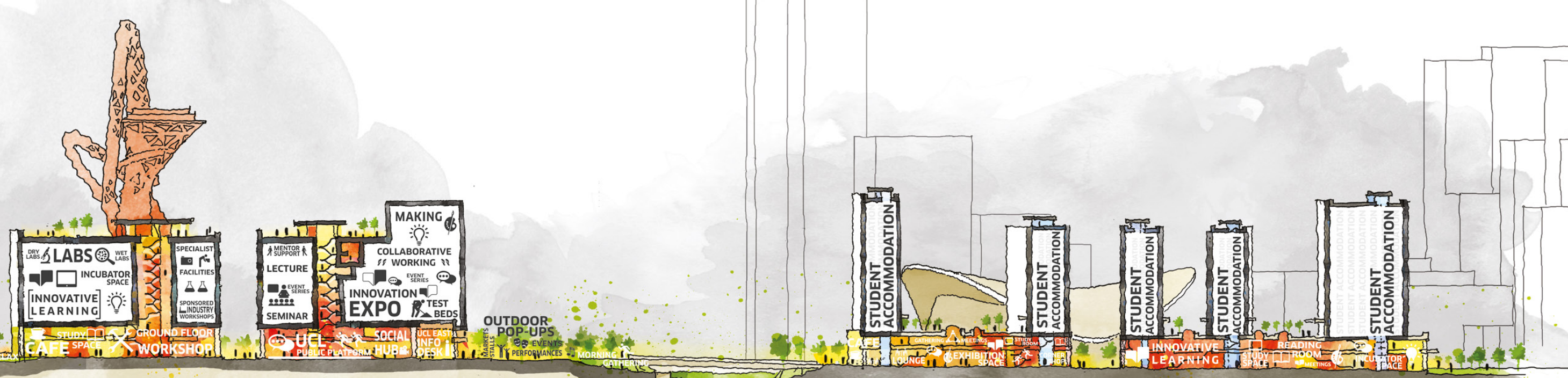


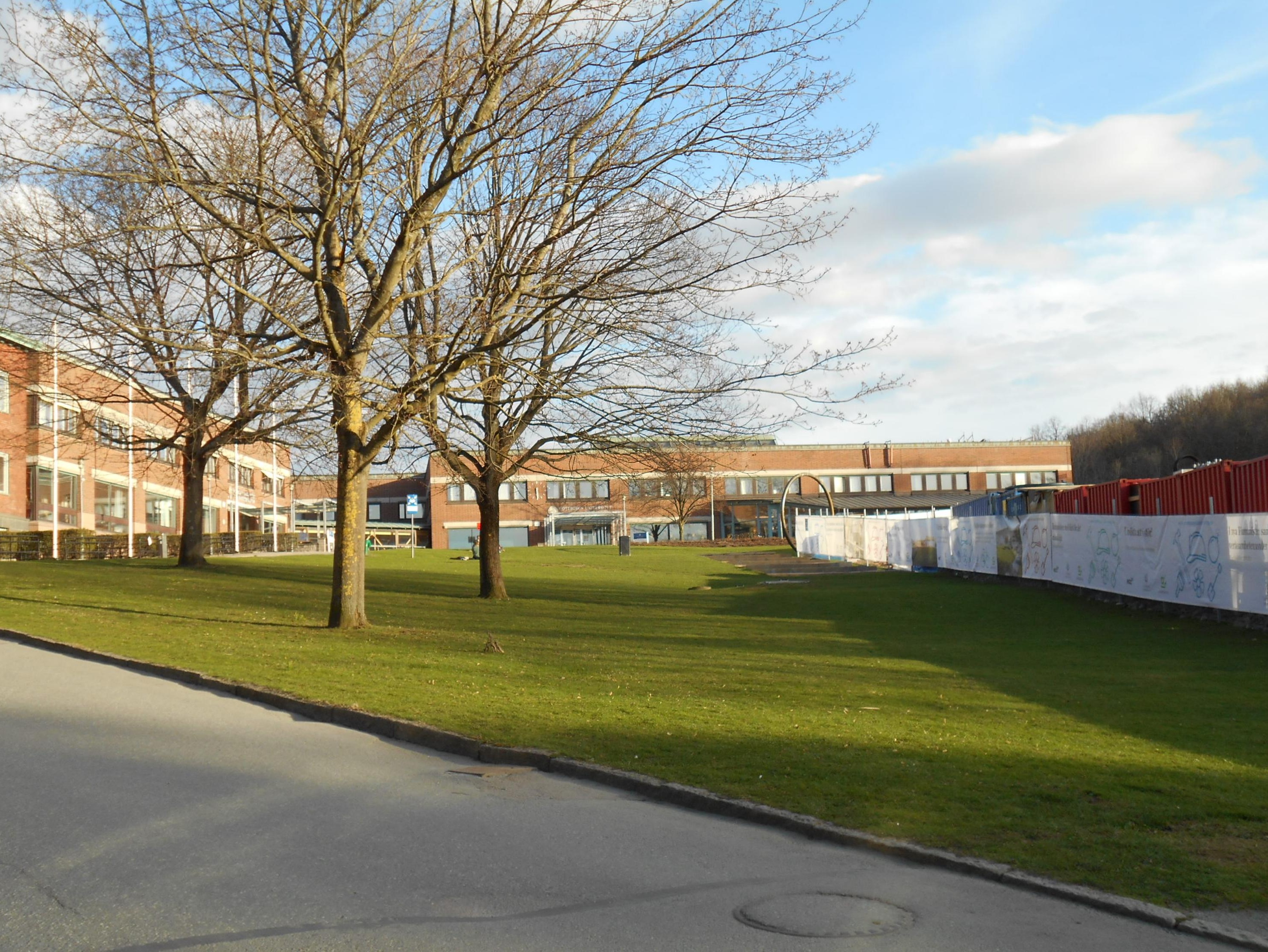






\section{Vi beklagar omvägen!}

Av säkerhetsskäl måste gång- och cykelvägen via Språkskrapan stängas av under Humanistens ombyggnadsperiod. Vi lämnar tillbaka den i uppdaterad form vid årsskiftet 2019/2020. Tack för visat tålamod!

Håll dig uppdaterad om projektet på: www.projekthumanisten.hum.gu.se
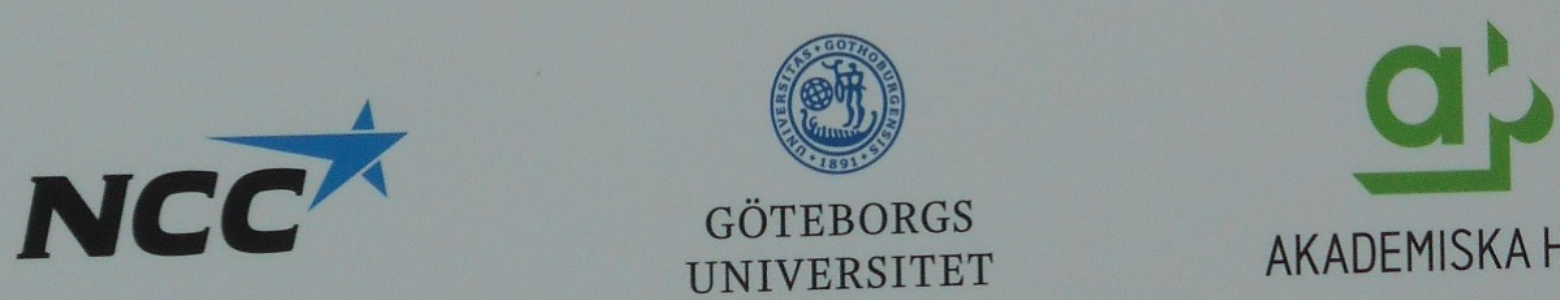

AKADEMISKA HUS 